\title{
Transaction modeling on e-Commerce
}

\section{Modelado de transacciones en comercio electrónico}

\author{
GONZÁLEZ-CASTOLO, Juan Carlos†**, RAMOS-CABRAL, Silvia, ZATARAIN-DURÁN, Omar Alí \\ and HERNÁNDEZ-RUEDA, Karen
}

\section{Universidad de Guadalajara}

ID $1^{\text {st }}$ Author: Juan Carlos, González-Castolo / ORC ID: 0000-0003-2659-0646, Researcher ID Thomson: R-5580-2018

ID $1^{\text {st }}$ Co-author: Silvia, Ramos-Cabral / ORC ID: 0000-0003-4204-1700, Researcher ID Thomson: R-7124-2018

ID $2^{\text {nd }}$ Co-author: Omar Alí, Zatarain-Durán / ORC ID: 0000-0002-7934-7765, Researcher ID Thomson: E-2222-2019

ID $3^{\text {nd }}$ Co-author: Karen, Hernández-Rueda / ORC ID: 0000-0002-7209-2907, Researcher ID Thomson: AAM-4861-2021

DOI: $10.35429 / J I O .2021 .8 .5 .1 .9$

Received March 28, 2021; Accepted June 20, 2021

\begin{abstract}
This article presents the formal representation of the sale and purchase transaction process that occurs in electronic commerce (e-Commerce). E-Commerce is an area of study that has acquired a marked interest in recent times. A direct transaction between provider and consumer is analyzed with two variants of the resulting model that follows the criteria considered from a representation of conceptual maps. The conceptual map resembles a graph, with labels of concepts associated with the nodes and labels, of connectors between concepts, associated with the arcs. The description of the process, using conceptual maps, is accompanied by a narrative of events. Conceptual maps are used because they are a resource that facilitates the presentation of complex processes and gives way to their formalization. Formalizing a process is convenient because it enables its subsequent analysis, modification, improvement, control, and/or monitoring. The previous formal representation consists of a graph and a series of equations derived from the narrative sequence of the conceptual map.
\end{abstract}

\section{E-commerce, ICT, Modeling}

\begin{abstract}
Resumen
Este artículo presenta la representación formal del proceso de transacción de compraventa que ocurre en el comercio electrónico. El comercio electrónico es un área de estudio que adquiere un acentuado interés en últimas fechas. Se analiza una transacción directa entre proveedor y consumidor con dos variantes del modelo resultante que obedece a los criterios tomados en cuenta desde una presentación dada en mapas conceptuales. El mapa conceptual se asemeja a un grafo, con etiquetas de conceptos asociados a los nodos y etiquetas, de conectores entre conceptos, asociadas a los arcos. La descripción del proceso, utilizando mapas conceptuales, se acompaña de una narración de sucesos. Se utilizan los mapas conceptuales porque son un recurso que facilita la exposición de procesos complejos y da paso a su formalización. Formalizar un proceso es conveniente porque posibilita su posterior análisis, modificación, mejora, control y/o seguimiento. La representación formal aludida, consiste en un grafo y una serie de ecuaciones que se derivan de la secuencia narrativa del mapa conceptual.
\end{abstract}

Comercio electrónico, TIC, Modelado

Citation: GONZÁLEZ-CASTOLO, Juan Carlos, RAMOS-CABRAL, Silvia, ZATARAIN-DURÁN, Omar Alí and HERNÁNDEZ-RUEDA, Karen. Transaction modeling on e-Commerce. Rinoe Journal-Industrial Organization. 2021. 5-8:19

\footnotetext{
* Correspondence to Author (email:jcgcastolo@hotmail.com)

$\dagger$ Researcher contributing first author.
} 


\section{Introduction}

In recent years, the development and use of information and communication technologies (ICT) have driven change in society (Coccia, 2019), economic (Makoza, 2020), and political paradigms worldwide (Klymash, Demydov, Uryvskyi, \& Pyrih, 2020) (Adam, 2020). The extensive use of the ICT is as a highway that facilitates the massive communication breaking the barrier of distance and time (Dhamacharoen, Kumpusiri, \& Waiyakarn, 2019) (Arrieta Avendaño \& Ruiz Verde, 2020).

The high penetration of the use of ICTs covers both organizations (Kim \& Kim, 2020) and people (y Murillo de la Cueva \& D'Antonio Maiceras, 2019). In organizations, the use of ICTs is observed in market studies (Nasida Binta Wahab , Salauddin , \& Moniruzzaman, 2019), administration (Islam, 2016), e-Commerce transactions (Xin, Yiming, \& Chang, 2020) (Velázquez López, Martínez Carballo, \& Torres Hechavarría, 2021), etc. On the other hand, ICTs are present among people in many aspects of their daily lives and it is accentuated in the use of platforms to establish social networks (Shahbaznezhad, Dolan, \& Rashidirad, 2021) (Aldemar, 2020) and buy things online (Ah Fook \& McNeill,, 2020) (Morillo Ridaura \& Baviera Puig, 2021). Then, there is notable growth in $e$ Commerce (Agarwal \& Terry, 2015).

Various studies have been carried out in relation to e-Commerce such as marketing (Xiang, 2020) (Li, Guo, Sheng, \& Chen, 2020), market study (Ebad, 2018), customer satisfaction (Anisah \& Suhendra, 2018), production level (Wang, Chai, \& Liu, 2018), quality (Gajewska, Zimon, Kaczor, \& Madzík, 2020), etc.

In e-Commerce, transactions are the most critical condition in the sale-purchase process (Barkatullah \& Djumadi , 2018) (Ilmudeen , 2019). Some studies affirm that the future of eCommerce depends on the development of extra-judicial mechanism for conflict resolution adapted to internet dynamics (Przemysław Polan, 2017) (Albrecht, 2018). The mechanisms are called online dispute resolution (ODR) and they need to be able to provide the same security and trust to consumers and merchants, however there is no agreed international ODR (González \& Nava González, 2020).
Electronic transactions have been studied from different points of view, for example: from the point of view of the provider (Cardoso \& Martínez, 2019) (Acosta Carlos, Gómez Ramos , \& Peña Quitiaquez, 2020), from the point of view of the consumer (Sheshasaayee \& Logeshwari, 2018), from the point of view of the State (Dumortier, 2014), from the bank's point of view (Salamah, 2017), etc. To make the transaction process explicit from any point of view, a formal method of representation is proposed in this paper. This article is organized as follows. The following section presents the glossary of definitions followed by the theoretical framework about conceptual maps used. The transaction modeling example is shown, and a variant is also included. Finally, the conclusions are given.

\section{Definition glossary}

Greed state $(G s)$ : the emotional level at which a consumer (Cmer) is willing to buy a product.

Product $(P)$ : a service and/or object that is offered in the market.

Consumer (Cmer): the entity that acquires a $\mathrm{P}$ through a purchase-sale transaction (pst).

Entity: the organization or individual.

Purchase-sale transaction (pst): Process to pay with money and receive a $\mathrm{P}$ in exchange. To simplify the language, this will be called transaction only.

Provider (Pder): the entity that offers its $\mathrm{P}$ looking for a pst for said $\mathrm{P}$.

In the context of e-Commerce, the Cmer and Pder are online consumed and provider, respectively. They are called as econsumer (eCmer) and eprovider (ePder).

Or operator: logical operator that origin a false conclusion when the premises are false.

\section{Conceptual map formalism}

A conceptual map is a tool of knowledge representation that resembles a bi-graph where each concept is a node. Arcs are used to relate concepts. The distribution of a conceptual map follows a logical link. 


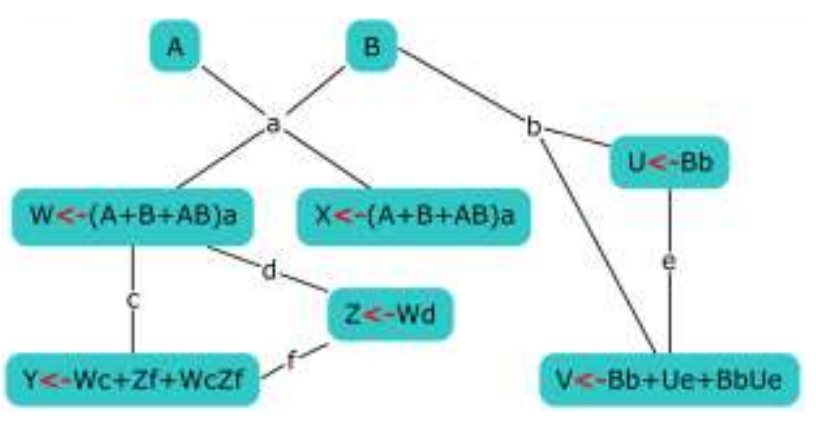

Figure 1 Logical conceptual map with arcs input criteria Own Source

\section{Input criteria}

Figure 2 shows that the $W$ concept is justified by the or operator on $A, B$, and the modifier $a$ that relates them to $W,(1)$.

$$
\begin{aligned}
W & \leftarrow(A \text { or } B) a \\
\leftarrow & (A+B+A B) a
\end{aligned}
$$

After the distributive operation, the (2) is obtained and it is reading as if $a A$ or $B a$ or $(A$ and $B$ )a then $W$.

$$
W \leftarrow A a+B a+(A B) a
$$

Some elements cannot be present in $W$ because they are incongruous and/or unnecessary to it explain. Then $W$ could also be justified by (3).

$$
\begin{aligned}
W & \leftarrow \quad A a \\
& \leftarrow \quad B a \\
& \leftarrow A a+B a \\
& \leftarrow A a+(A B) a \\
& \leftarrow B a+(A B) a
\end{aligned}
$$

The $A a$ element is the $A$ concept modified by $a$. In other words, $A$ is related with $W$ by $a$. The $A a$ is equivalent to $a A$ and, the (AB) $a$ means that each concept is modified by $a$, (4). The concept could be referent to an action. In this case, $(A B) a$ indicates that $A a$ and $B a$ occur at the same time.

$$
\begin{array}{ccc}
A a & \equiv & a A \\
(A B) a & \equiv & A a B a
\end{array}
$$

The $X$ node is justified by the same nodes of $W$ but $X$ is always different that $W$ by (3). The time variable is present to determine the difference between them. The concept $V$ is explained by two concepts with a different relationship to each one. Here, the operator or is present as equation (1) that explained $W$.
Every node has associated one or more modifiers. This is highlighted in $Y$, (5).

$$
\begin{array}{ccc}
Y & \leftarrow & W c+Z f+W c Z f \\
\text { as } & & W d \\
Z & \leftarrow & \\
\text { then } & & \\
Y & \leftarrow & W c+W d f+W c W d f
\end{array}
$$

In $V$ node is presented an atypical case, (6).

$$
\begin{array}{ccc}
V & \leftarrow & B b+U e+B b U e \\
a s & & B b \\
U & \leftarrow & \\
\text { then } & & \\
V & \leftarrow & B b+B b e+B b B b e
\end{array}
$$

Then $B b$ is different from $B b e$. The $B b e$ is a simplify expression of $(B b) e$. In this case, the expressions generated by (4) are limited (7).

$$
\begin{aligned}
\text { Bbe } & \equiv(B b) e \\
& \equiv(b B) e \\
& \neq b B e \\
& \neq b(B e)
\end{aligned}
$$

\section{Output criteria}

Figure 2 shows that $W$ and/or $Z$ concepts justify $Y$ with the $c, f$ modifiers, respectively. Additionally, $W$ with $d$ justifies $Z$. The $A$ and/or $B$ concepts justify $W$ with $a$ modifier (8).

$$
\begin{array}{ccc}
A & \rightarrow & W a+X a+\text { WaXa } \\
a s & & Y f \\
Z & \rightarrow & Y c+Z d+Y c Z d \\
W & \rightarrow & Y c+Y f d+Y c Y f d \\
& \rightarrow & \\
\text { then } & & \\
A & \rightarrow & (Y c+Y f d+Y c Y f d) a+X a+ \\
& & (Y c+Y f d+Y c Y f d) a X a \\
& \rightarrow & Y c a+Y f d a+Y c a Y f d a+X a+ \\
& & Y c a X a+Y f d a X a+Y c a Y f d a X a
\end{array}
$$

The expression of the node $A$ has been expanded for the didactic purpose (7) but is enough with the initial representation as shown in Figure 2. 


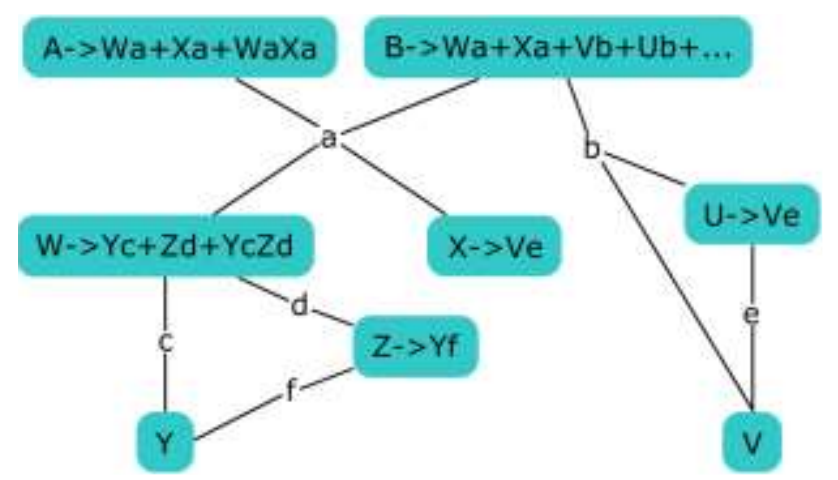

Figure 2 Logical conceptual map with arcs output criteria Own Source

Even with a contained representation, the equation for node $B$ remains large, (9).

$$
\begin{aligned}
& B \leftarrow \quad W a+X a+V b+U b+ \\
& W a X a+W a V b+W a U b+ \\
& X a V b+X a U b+V b U b+ \\
& W a X a V b+W a X a U b+X a V b U b+ \\
& \text { WaXaVbUb }
\end{aligned}
$$

The modifier could be omitted in the contained representation when it is not critical to explain the relation. In this case (9) is expressed as (10).

$$
\begin{aligned}
& B \quad W+X+V+U+ \\
& W X+W V+W U+ \\
& X V+X U+V U+ \\
& W X V+W X U+X V U+ \\
& W X V U
\end{aligned}
$$

The formal conceptual map could be represented with a graph and input and output equations of each node, Figure 3.

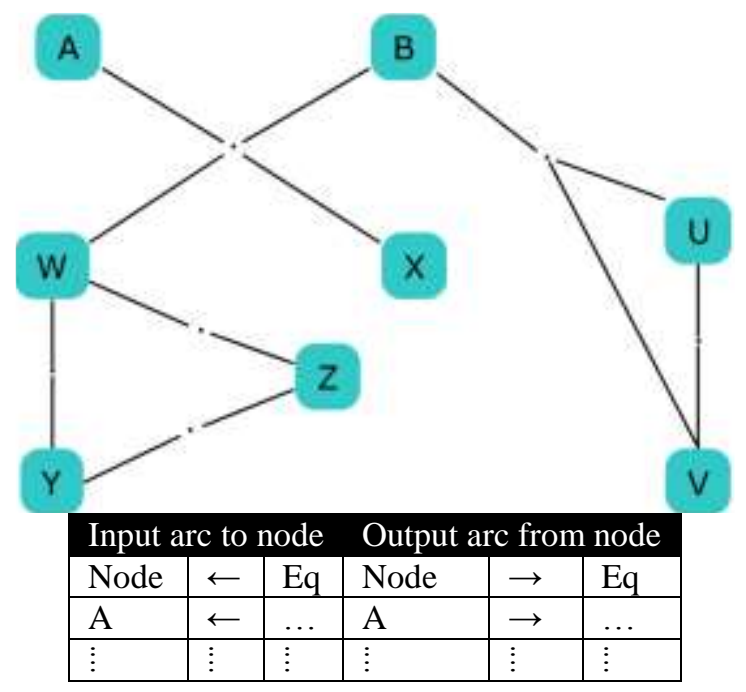

Figure 3 Formal conceptual map representation Own Source

\section{Transaction modeling}

If payment for a product is received directly by the ePder, then it is a direct transaction. The payment could be with an intermediary and this case is an indirect transaction. When the payment could be received directly and indirectly is say hybrid transaction. In this work, the direct transaction is shown in Figure 4. Table 1 has its description. The $a, b, c, d, e$ arcs are essential to explain the relationships between some nodes.

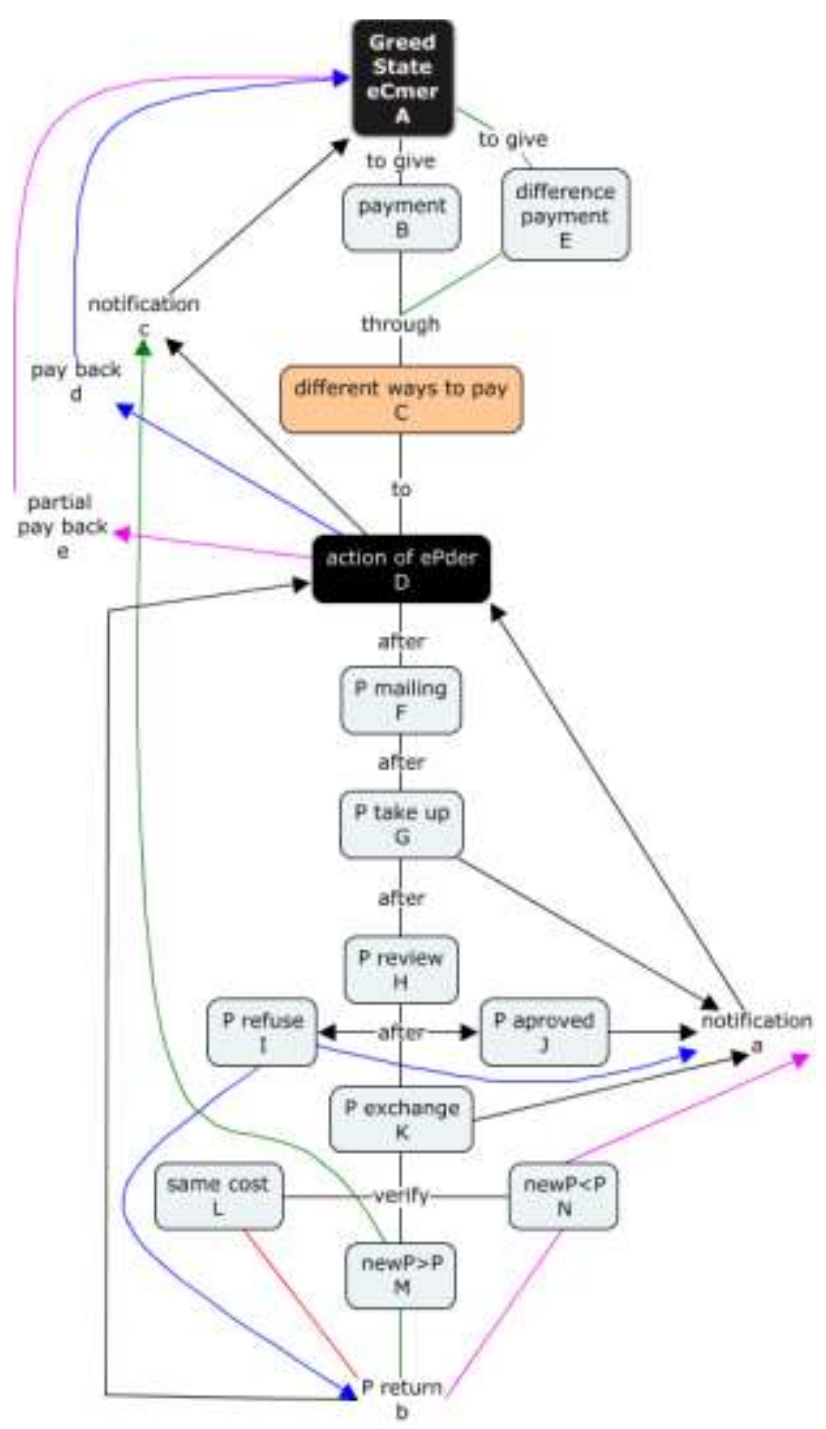

Figure 4 Conceptual map of e-Commerce transaction Own Source 


\begin{tabular}{|c|c|c|}
\hline Node & $\operatorname{arc}$ & Description \\
\hline$A$ & & The eCmer has a $G s$ \\
\hline$B$ & & $e C m e r$ going to pay to $e P d e r$ \\
\hline $\bar{C}$ & & $\begin{array}{l}\text { The payment is through different } \\
\text { electronic ways }\end{array}$ \\
\hline$D$ & & $\begin{array}{l}\text { After } e P d e r \text { received the money, he has } \\
\text { taken steps to attend } e C m e r\end{array}$ \\
\hline & $\mathrm{c}$ & $\begin{array}{l}\text { The } e C m e r \text { is notified that } e P d e r \text { has been } \\
\text { received the money }\end{array}$ \\
\hline$F$ & & $e P d e r$ send $P$ in a parcel service \\
\hline$G$ & & The $e$ Cmer receives $P$ \\
\hline & $\mathrm{a}$ & Notifies to $e P d e r$ that $e C m e r$ has $P$ \\
\hline$H$ & & $\begin{array}{l}\text { eCmer does review } P \text { and takes a decision } \\
(I, J, K)\end{array}$ \\
\hline$I$ & & $e C m e r$ refuses $P$ \\
\hline & $a$ & $\begin{array}{l}\text { Notifies to } e P d e r \text { that } e \text { Cmer has refused } \\
P\end{array}$ \\
\hline & $b$ & $e C m e r$ returns $P$ to $e P d e r$ \\
\hline$D$ & & $e P d e r$ has taken steps to attend $e C m e r$ \\
\hline & $d$ & $\begin{array}{l}e P d e r \text { return the payment to } e \text { Cmer and } \\
\text { the transaction is finished }\end{array}$ \\
\hline$J$ & & $e C m e r$ is satisfied with $P$ \\
\hline & $a$ & $\begin{array}{l}\text { Notifies to } e P d e r \text { that } e \text { Cmer is satisfied } \\
\text { with } P \text { and the transaction is finished }\end{array}$ \\
\hline$K$ & & $\begin{array}{l}e C m e r \text { wants to change } P \text { and three cases } \\
\text { are presented }(L, M, N)\end{array}$ \\
\hline & $a$ & $\begin{array}{l}\text { Notifies to } e P d e r \text { that } e C m e r \text { wants to } \\
\text { change } P\end{array}$ \\
\hline$L$ & & Price $P$ is the same as the new selected $P$ \\
\hline & $b$ & $\begin{array}{l}e C m e r \text { returns } P \text { to } e P d e r \text { and the } \\
\text { transaction cycle continue }\end{array}$ \\
\hline$M$ & & Price of the new selected $P$ is higher \\
\hline & $b$ & $e C m e r$ returns $P$ to $e P d e r$ \\
\hline & $c$ & $\begin{array}{l}\text { Notifies to } e C m e r \text { that it is necessary to } \\
\text { cover a price difference }\end{array}$ \\
\hline$A$ & & $\begin{array}{l}\text { eCmer takes steps to cover a price } \\
\text { difference }\end{array}$ \\
\hline$E$ & & $\begin{array}{l}\text { eCmer going to pay the difference to } \\
e P d e r\end{array}$ \\
\hline$C$ & & $\begin{array}{l}\text { The payment is through different } \\
\text { electronic ways }\end{array}$ \\
\hline$D$ & & $\begin{array}{l}\text { After } e P d e r \text { received the money and } P \text {, he } \\
\text { has taken steps to attend } e C m e r \text { and the } \\
\text { transaction cycle continue }\end{array}$ \\
\hline$N$ & & Price of the new selected $P$ is lower \\
\hline & $b$ & $e C m e r$ returns $P$ to $e P d e r$ \\
\hline & $a$ & $\begin{array}{l}\text { Notifies to } e P d e r \text { that the price of the new } \\
\text { selected } P \text { is lower }\end{array}$ \\
\hline$D$ & & $\begin{array}{l}\text { After } e P d e r \text { received } P \text {, he has taken } \\
\text { steps to attend } e C m e r \text { and the transaction } \\
\text { cycle continue }\end{array}$ \\
\hline & $e$ & $\begin{array}{l}e P d e r \text { return the partial payment to } \\
e C m e r\end{array}$ \\
\hline
\end{tabular}

Table 1. Description of $e$-Commerce transaction Own Source

The entry and/or exit arcs to $D$ or $A$ does not occur at the same time. This asynchrony is noticeable when using different colors.

Figure 5 and Table 2 are the formal conceptual map.

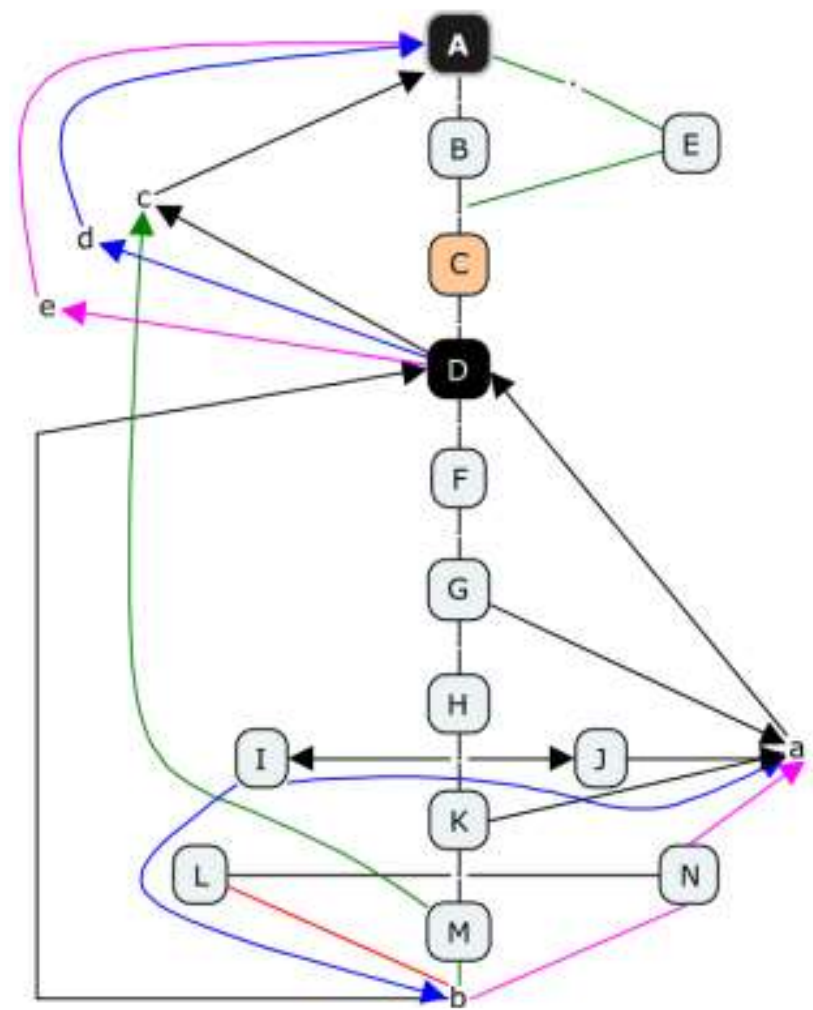

Figure 5 Graph to represent the transaction Own Source

\begin{tabular}{|l|l|l|}
\hline \multicolumn{3}{|l|}{ input arc to node } \\
\hline$B$ & $\leftarrow$ & $A$ \\
\hline$E$ & $\leftarrow$ & $A$ \\
\hline$C$ & $\leftarrow$ & $B+E$ \\
\hline$D$ & $\leftarrow$ & $\begin{array}{l}C+(G+I+J+K+N) a+(I+L+M+N) b+ \\
(G+I+J+K+N) a(I+L+M+N)\end{array}$ \\
\hline$F$ & $\leftarrow$ & $D$ \\
\hline$G$ & $\leftarrow$ & $F$ \\
\hline$H$ & $\leftarrow$ & $G$ \\
\hline$I$ & $\leftarrow$ & $H$ \\
\hline$J$ & $\leftarrow$ & $H$ \\
\hline$K$ & $\leftarrow$ & $H$ \\
\hline$L$ & $\leftarrow$ & $K$ \\
\hline$M$ & $\leftarrow$ & $K$ \\
\hline$N$ & $\leftarrow$ & $K$ \\
\hline$A$ & $\leftarrow$ & $(D+M) c+D d+D e+D c D d+D c D e$ \\
\hline output & $a r c$ & $f r o m$ \\
\hline$A$ & $\rightarrow$ & $B+E$ \\
\hline$B$ & $\rightarrow$ & $C$ \\
\hline$E$ & $\rightarrow$ & $C$ \\
\hline$C$ & $\rightarrow$ & $D$ \\
\hline$D$ & $\rightarrow$ & $A c+A d+A e+F+F A c+F A c A e+F A e+A c A d$ \\
\hline$F$ & $\rightarrow$ & $G$ \\
\hline$G$ & $\rightarrow$ & $H+D a+H D a$ \\
\hline$H$ & $\rightarrow$ & $I+J+K$ \\
\hline$I$ & $\rightarrow$ & $D a+D b+D a D b$ \\
\hline$J$ & $\rightarrow$ & $D a$ \\
\hline$K$ & $\rightarrow$ & $D a+L+M+N+D a L+D a M+D a N$ \\
\hline$L$ & $\rightarrow$ & $D b$ \\
\hline$M$ & $\rightarrow$ & $D b+A c+D b A c$ \\
\hline$N$ & $\rightarrow$ & $D b+D a+D b D a$ \\
\hline & & \\
\hline
\end{tabular}

Table 2 Equations on each node of the graph Own Source 
Figure 6 shows the tree coverture of $e$ Commerce transactions, and this is obtained from Table 1. The green nodes are the end of the branch. The nodes with three dots mean that the e-Commerce transaction circle continues. The nodes move from one to the other as their description completes.

From Figure 6, the $a, b, c, d$, and $e$, arcs may originally be nodes on the Figure 7 . The description and tree coverture do not change. The formal description is presented by Figure 8 and Table 3.

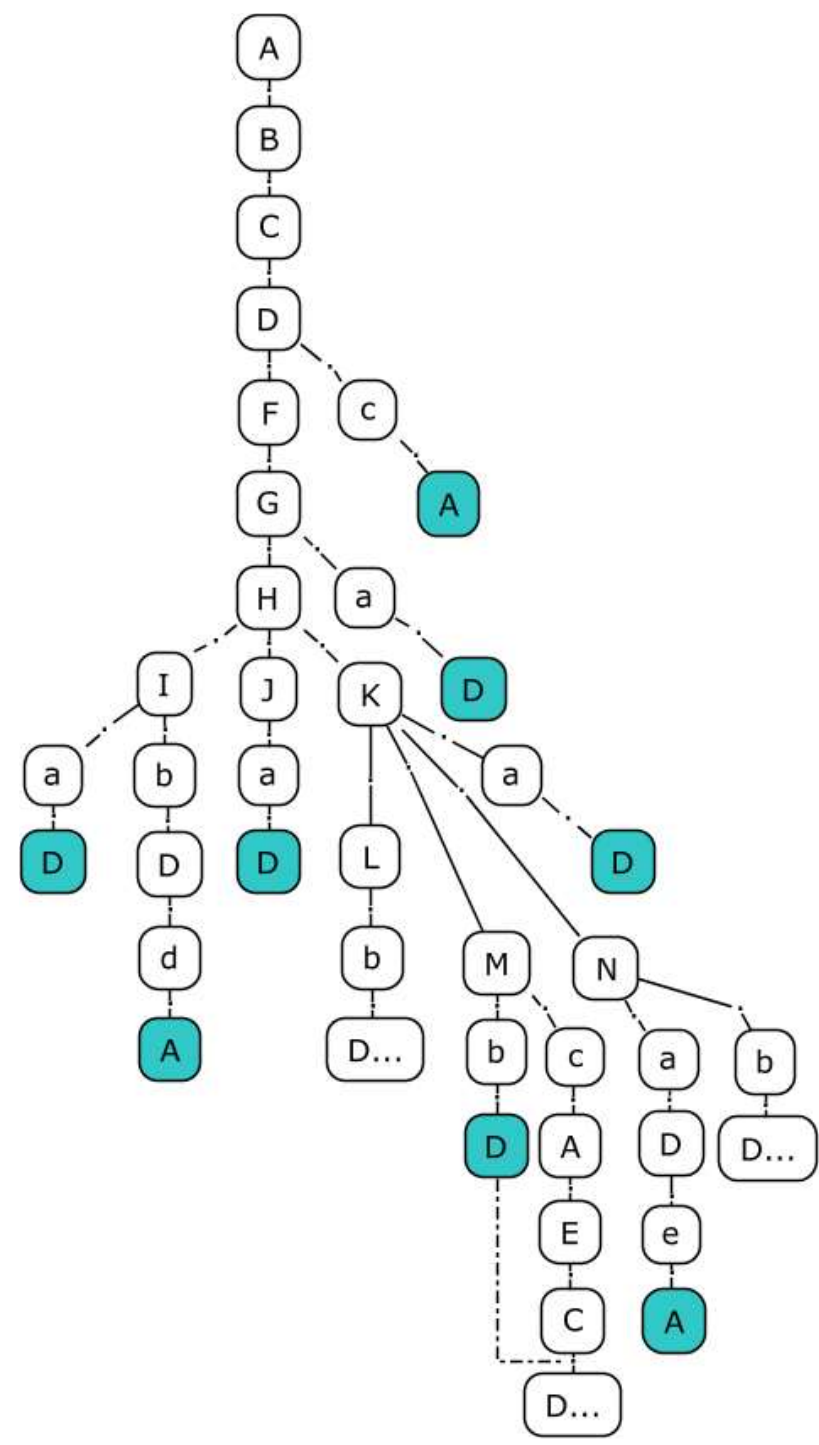

Figure 6 Tree coverture of e-Commerce transaction Own Source

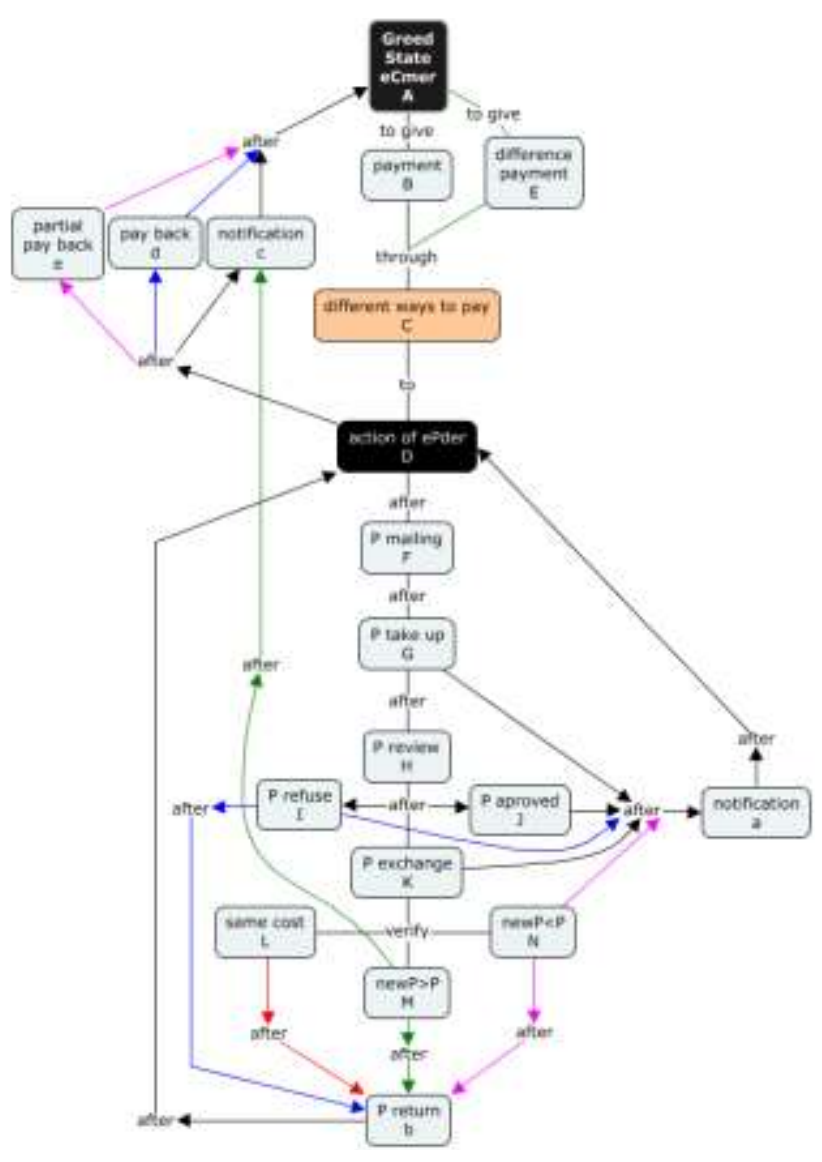

Figure 7 Conceptual map of e-Commerce transaction without relevant arcs

Own Source

\begin{tabular}{|l|c|l|}
\hline \multicolumn{3}{|l|}{ input arc to node } \\
\hline$B$ & $\leftarrow$ & $A$ \\
\hline$E$ & $\leftarrow$ & $A$ \\
\hline$C$ & $\leftarrow$ & $B+E$ \\
\hline$D$ & $\leftarrow$ & $C+a+b+a b$ \\
\hline$F$ & $\leftarrow$ & $D$ \\
\hline$G$ & $\leftarrow$ & $F$ \\
\hline$H$ & $\leftarrow$ & $G$ \\
\hline$I$ & $\leftarrow$ & $H$ \\
\hline$J$ & $\leftarrow$ & $H$ \\
\hline$K$ & $\leftarrow$ & $H$ \\
\hline$L$ & $\leftarrow$ & $K$ \\
\hline$M$ & $\leftarrow$ & $K$ \\
\hline$N$ & $\leftarrow$ & $K$ \\
\hline$A$ & $\leftarrow$ & $c+d+e+c e+c d$ \\
\hline$a$ & $\leftarrow$ & $G+I+J+K+N$ \\
\hline$b$ & $\leftarrow$ & $I+L+M+N$ \\
\hline$c$ & $\leftarrow$ & $D+M+D M$ \\
\hline$d$ & $\leftarrow$ & $D$ \\
\hline$e$ & $\leftarrow$ & $D$ \\
\hline output arc from $n$ node \\
\hline$n s e r t e ́ A$ & $\rightarrow$ & $B+E$ \\
\hline$B$ & $\rightarrow$ & $C$ \\
\hline$E$ & $\rightarrow$ & $C$ \\
\hline$C$ & $\rightarrow$ & $D$ \\
\hline$D$ & $\rightarrow$ & $F+c+d+e+F c+F e+F c e+c d$ \\
\hline$F$ & $\rightarrow$ & $G$ \\
\hline$G$ & $\rightarrow$ & $H+a+H a$ \\
\hline$H$ & $\rightarrow$ & $I+J+K$ \\
\hline$I$ & $\rightarrow$ & $a+b+a b$ \\
\hline$J$ & $\rightarrow$ & $a$ \\
\hline$K$ & $\rightarrow$ & $L+M+N+a+L a+M a+N a$ \\
\hline$L$ & $\rightarrow$ & $b$ \\
\hline & & \\
\hline$B$ & & \\
\hline & & \\
\hline & &
\end{tabular}

GONZÁLEZ-CASTOLO, Juan Carlos, RAMOS-CABRAL, Silvia, ZATARAIN-DURÁN, Omar Alí and HERNÁNDEZ-RUEDA, Karen. Transaction modeling on e-Commerce. Rinoe Journal-Industrial Organization. 2021 


\begin{tabular}{|l|l|l|}
\hline$M$ & $\rightarrow$ & $b+c+b c$ \\
\hline$N$ & $\rightarrow$ & $a+b+a b$ \\
\hline$a$ & $\rightarrow$ & $D$ \\
\hline$b$ & $\rightarrow$ & $D$ \\
\hline$c$ & $\rightarrow$ & $A$ \\
\hline$d$ & $\rightarrow$ & $A$ \\
\hline$e$ & $\rightarrow$ & $A$ \\
\hline
\end{tabular}

Table 3 Equations on each node of the graph without relevant arc Own Source

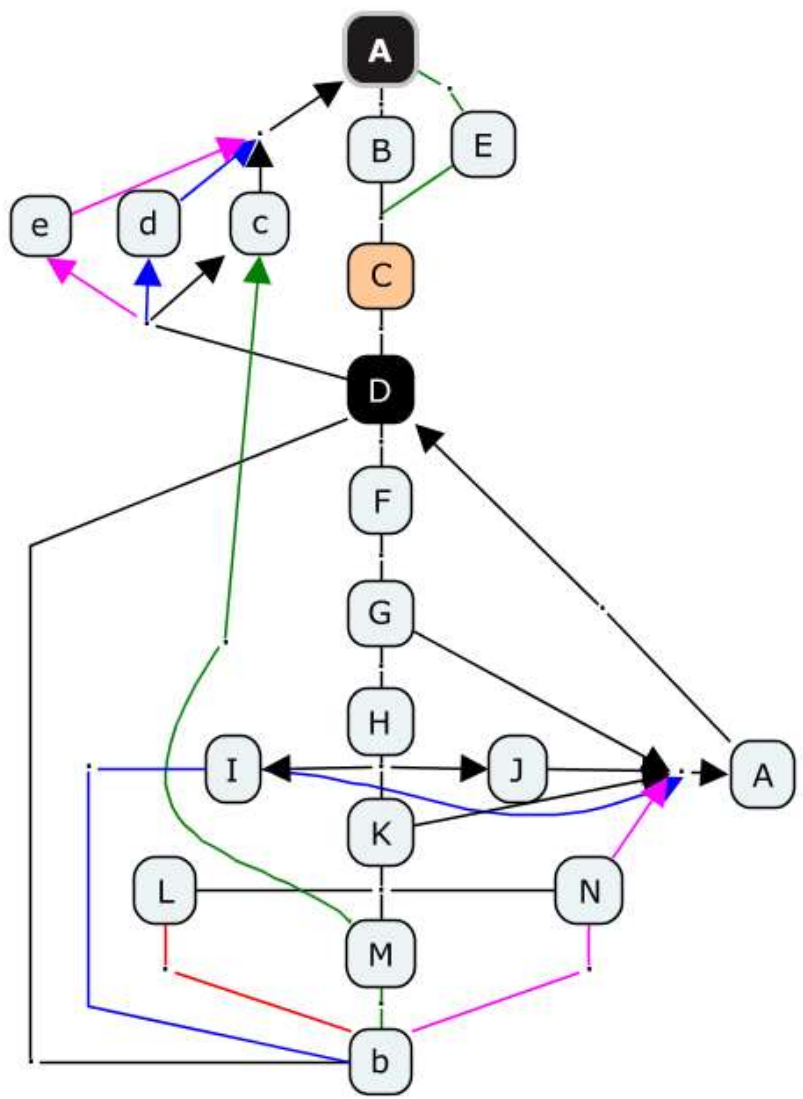

Figure 8 Graph to represent the transaction without relevant arc

Own Source

The equations from Table 3 are equivalent to the equations of Table 2. The equation (11) shows and example of this equivalence

$$
\begin{array}{cccc}
A & \leftarrow & c+d+e+c e+c d \\
& \leftarrow & (D+M+D M) c+D d+D e+ \\
D M & \equiv & (D+M+D M) c D e+(D+M+D M) c l \\
A & \leftarrow & \emptyset \\
& & (D+M) c+D d+D e+ \\
& \leftarrow & (D+M) c+D d+D e+ \\
M c D e & \equiv & M c D e+D c D d+M c D d \\
M c D d & \equiv & \emptyset \\
A & \leftarrow & (D+M) c+D d+D e+D c D e+D c D \iota
\end{array}
$$

In the development of (11) some terms are null because they never happen in the transaction.

\section{Conclusions}

This paper presented a description of the elementary sale-purchase transaction. The transaction can be described using conceptual maps in an easy way, but this is not enough to analyze the process. The proposal is a formal model that facilitates his analysis. The model consists of a graph and equations of input and output from nodes. The work concludes with the model, but the research continues about the analysis method, modification method, and/or transform this to Petri net representation.

\section{References}

Acosta Carlos , J. F., Gómez Ramos , B. M., \& Peña Quitiaquez, D. S. (2020). Análisis de la logística del comercio electrónico en la cadena de valor $B 2 C$ en Colombia. Bogotá: Universitaria Agustiniana Facultad de Ciencias Económicas y Administrativas Programa de Negocios Internacionales.

Adam, I. O. (May de 2020). Examining EGovernment development effects on corruption in Africa: The mediating effects of ICT development and institutional quality. Technology in Society, 61.

Agarwal, J., \& Terry, W. (2015). Factors Influencing Growth Potential of E-Commerce in Emerging Economies: An Institution-Based NOLI Framework and Research Propositions. Factors Influencing Growth Potential of ECommerce in Emerging Economies: An Institution-Based N-OLI Framework and Research Propositions, 57, 197-215.

Ah Fook, L., \& McNeill,, L. (September de 2020). "Click to Buy: The Impact of Retail Credit on Over-Consumption in the Online Environment," Sustainability. MDPI, Open Access Journal, 12(18), 1-15.

Albrecht, D. (2018). "China'S New ECommerce Law. Computer Law Review International, 19(5), 163-164.

Aldemar, R. H. (2020). Trabajo de grado de núcleo de apoyo contable y fiscal: Sensibilización en el comercio electrónico informal por medio de redes sociales en Medellín. Medellín, Colombia: Universidad Corporativa de Colombia. 
Anisah, R., \& Suhendra, A. (2018). Customer Satisfaction, and Perceived Effectivenes of ECommerce Institutional Mechanism to Repurchase Intention: Systematic Literature Review. . Journal of Physics: Conference Series. 1060(1):012041.

Arrieta Avendaño, C. C., \& Ruiz Verde, E. M. (2020). Un nuevo modelo de negocio para los operadores logísticos de comercio exterior. Lima.

Barkatullah, A. H., \& Djumadi . (2018, JulyAugust). Does self-regulation provide legal protection and security to e-commerce consumers? Electronic Commerce Research and Applications, 30, 94-101.

Cardoso, S., \& Martínez, L. (2019). Online payments strategy: how third-party internet seals of approval and payment provider reputation influence the Millennials' online transactions. Electron Commer Res 19, 189-209.

Coccia, M. (4 de April de 2019). Why do nations produce science and technology in society? Technology in Society, 59, s/n.

Dhamacharoen, A., Kumpusiri, P., \& Waiyakarn, S. (2019). Consumers Perceptions Towards Buying Evaluation and Perceived Risks of E-Commerce Products: A Study on Influencing Factors. Retrieved May 2020, from SSRN:

https://papers.ssrn.com/sol3/papers.cfm?abstrac t_id=3316930

Dumortier, J. (23 de July de 2014). Regulation (EU) No 910/2014 on electronic identification and trust services for electronic transactions in the internal market (eIDAS Regulation). Official Journal of the European Union.

Ebad, S. (26 de April de 2018). An exploratory study of ICT projects failure in emerging markets. Journal of Global Information Technology Management, 21(2), 139-160.

Gajewska, T., Zimon, D., Kaczor, G., \& Madzík, P. (21 de April de 2020). The impact of the level of customer satisfaction on the quality of ecommerce services. International Journal of Productivity and Performance Management, 69(4), 666-684.
González, N., \& Nava González, W. (2020). Los mecanismos extrajudiciales de resolución de conflictos en línea: su problemática en el derecho internacional privado. ACDI, 13, 187208.

Ilmudeen , A. (2019). SSRN. Retrieved May 2020, from https://papers.ssrn.com/sol3/papers.cfm?abstrac t_id $=3344618$

Islam, N. (2016). The Use of Information and Communication Technology (ICT) and Business Management: Contemporary Issues and Challenges. SSRN Electronic Journal, s/n.

Kim, S.-B., \& Kim, D. (22 de Abril de 2020). ICT Implementation and Its Effect on Public Organizations: The Case of Digital Customs and Risk Management in Korea. Sustainability, 12(3421), 19.

Klymash, M., Demydov, I., Uryvskyi, L., \& Pyrih, Y. (2020). A Brief Survey on Architecture of Feedback Systems for Interactive EGovernment ICT Platforms. 15th International Conference on Advanced Trends in Radioelectronics, Telecommunications and Computer Engineering (TCSET), 458-461.

Li, X., Guo, Y., Sheng, Y., \& Chen, Y. (July de 2020). Characterizing Social Marketing Behavior of E-commerce Celebrities and Predicting Their Value. IEEE Conference on Computer Communications Workshops (INFOCOM WKSHPS).

Makoza, F. (2020). The Role of ICT in the Economic Recovery Plan of Malawi a Critical Discourse Analysis. International Journal of ICT Research in Africa and the Middle East, 9(1), 91-110.

Morillo Ridaura, M. A., \& Baviera Puig, T. (2021). El estudio del caso Amazon: Lecciones del líder en el comercio electrónico. Universidad Politécnica de Valencia.

Nasida Binta Wahab , T., Salauddin , M., \& Moniruzzaman, M. (28 de 06 de 2019). Use of ICT in decision making of agricultural marketing: Factors determining of farmers' involvement. Journal of the Bangladesh Agricultural University, 17(2), 226-231. 
Przemysław Polan, P. (June de 2017). Revisiting country of origin principle: Challenges related to regulating e-commerce in the European Union. Computer Law \& Security Review, 34(3), 562581.

Salamah, N. (2017). Impact of Electronic Banking Services on Bank Transactions. International Journal of Economics and Finance, 9(2).

Shahbaznezhad, H., Dolan, R., \& Rashidirad, M. (February de 2021). The Role of Social Media Content Format and Platform in Users' Engagement Behavior. Journal of Interactive Marketing, 53, 47-65.

Sheshasaayee, A., \& Logeshwari, L. (2018). Implementation of Clustering Technique Based RFM Analysis for Customer Behaviour in Online Transactions,. 2nd International Conference on Trends in Electronics and Informatics (ICOEI), 1166-1170.

Velázquez López, A., Martínez Carballo, M., \& Torres Hechavarría, L. (2021). Acciones para la gestión del comercio electrónico en la agendia de viajes cubana Ecotur. Revista Científica ECOCIENCIA, 8(1), 18-48.

Wang, L., Chai, Y., \& Liu, Y. (28 de Jylu de 2018). Wang, L., Chai, Y., \& Liu, Y. (2018). Analysis of Middlemen's Decisions on Production and Business Models in the ECommerce Environment. ICCSE'18. Business, Computer Science.

Xiang, F. (2020). Research on Computer Network Marketing in E-commerce. International Conference on Computer Engineering and Application (ICCEA), 303-305.

Xin, S., Yiming, L., \& Chang, C. (July de 2020). A Blockchain-Based P2P Transaction Method and Sensitive Data Encoding for E-Commerce Transactions. IEEE Consumer Electronics Magazine, 9(4), 56-66.

y Murillo de la Cueva, F., \& D'Antonio Maiceras, S. (2019). young people and social work: distances and opportunities. Social Work Education., 39(6), 813-824. 